\title{
SYMPOSIUM
}

\section{Diverse realities: sexually transmitted infections and HIV in India}

\section{S Hawkes, K G Santhya}

Sex Transm Infect 2002;78(Suppl I):i3 1-i39

There are many features that make India a vulnerable country as far as a sexually transmitted infection (STI)/HIV epidemic is concerned. These include the lack of a strong evidence base on which to formulate decision making, a pluralistic and often unregulated health sector, and a highly vulnerable population. Nonetheless, India has shown strong commitment to other areas of a comprehensive reproductive health care programme, and may be able to do so in the field of STI/HIV control. Vast numbers of people in India are severely disadvantaged in terms of income, education, power structures, and gender. Addressing these basic issues of human rights lies at the core of achieving better health outcomes.

See end of article for authors' affiliations

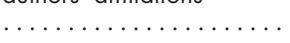

Correspondence to: Dr Sarah Hawkes, Clinical Research Unit, London School of Hygiene \& Tropical Medicine, Keppel Street, London WCIE 7HT UK

Accepted 30 November 2001
$\mathrm{P}$ olicy makers ideally set health sector priorities according to a number of variables including: burden of disease; whether effective "solutions" are available; and the calculated cost-effectiveness of those solutions. ${ }^{1}$ In the case of sexually transmitted infections (STI) in India, the epidemiological evidence base informing calculations of the burden of disease is limited. In this paper we highlight the known extent of the epidemic of STIs, including HIV, in India, risk factors and vulnerabilities to these infections, and the multifaceted responses to the epidemics. While in an ideal world it would be possible to talk about the "phases" (rising, stable, declining) of STI/HIV epidemics in India, in reality there is a dearth of longitudinal data from many areas of the country, and the exact phase of epidemics can only be guessed at.

\section{SOCIOECONOMIC VULNERABILITIES}

In May 2000, India joined China as one of only two countries with a population of more than one billion. National demographic characteristics reflect an environment vulnerable for STI transmission, including the following: a young population, with $36 \%$ aged below 15 years ${ }^{2}$; more men than women in the population (a ratio of 1000:933 in the 2001 census) $^{3}$; and an increasing pace of urbanisation. ${ }^{4}$ Migratory patterns are generally from impoverished rural areas to prospective urban destinations, especially in the more developed South. Most of the (predominantly male) migrants are married, and they leave behind their families in the villages and occasionally return to visit them. ${ }^{5}$ The highest reported prevalence of STIs during the period 1984-88 was in the southern/central states of Maharashtra and Tamil $\mathrm{Nadu}$, which were the most urbanised states in the country at the time of the 1981 census. ${ }^{6}$

A 1990s World Bank study of 50 low income countries noted that eight structural and behavioural level variables could explain up to two thirds of the variation in HIV prevalence between countries. ${ }^{7}$ India displays vulnerability in several of these variables: it is a low income country, with a GDP per capita of US\$465 in 1997'; absolute poverty is compounded by inequalities in income distribution-during the period 1990-96, while the poorest $40 \%$ shared $21 \%$ of the total household income, the richest $20 \%$ shared $43 \%$ of household income. ${ }^{9}$ Despite various initiatives to achieve universal primary education, in 2001 nearly half the adult female population was classed as non-literate. ${ }^{3}$

Women's status is low and their access to education, paid employment, and appropriate health care is limited. Life expectancy is almost equal between men and women, ${ }^{10}$ although a slight improvement in women's life expectancy over men's has been observed from the 1980s onwards. Disability Adjusted Life Years (DALYs) lost per annum are greater for women than men ${ }^{11}$ and the highest level of DALY disparity is in the reproductive age groups ( 15 to 44 years).

\section{BEHAVIOURAL RISK FACTORS}

Published reports on behavioural risks for STI/ HIV transmission must be interpreted with several methodological caveats. The definition of "sex" or "sexual partner" is not clearly articulated in many studies, thus raising difficulties with interpretation across and between studies. In addition, the prevailing family system in India is based on monogamous marital sex, with a high value placed on premarital chastity and marital fidelity, especially for women. Such cultural norms may influence respondents' willingness to report sexual activity. Despite these limitations, recent studies have provided valuable insights into the nature and extent of patterns of sexual behaviour in selected populations. A review of published studies highlights certain key areas.

\section{Commercial sex}

Prostitution, or sex work, has a very long history in India; the topic was discussed in texts written as far back as the third century BC. ${ }^{12}$ Today, female sex workers can broadly be categorised into four groups: brothel based; home based and part time; street based; and call girls. ${ }^{13}$ Women work in a variety of locations, and have different levels of independence or restrictions accordingly. 
Table 1 Published prevalence of sexually transmitted infection in men in India

\begin{tabular}{|c|c|c|c|c|c|c|c|c|c|}
\hline \multirow[b]{2}{*}{ Study population } & \multicolumn{9}{|c|}{ Prevalence ranges (\%) } \\
\hline & GC & CT & Syphilis & $\begin{array}{l}\text { Chancroid } \\
\text { (clinical } \\
\text { diagnosis) }\end{array}$ & TV & $\begin{array}{l}\text { HSV } \\
\text { (clinical } \\
\text { diagnosis) }\end{array}$ & $\begin{array}{l}\text { HPV } \\
\text { (clinical } \\
\text { diagnosis) }\end{array}$ & $\mathrm{HbsAg}$ & HIV \\
\hline \multicolumn{10}{|l|}{ Community based or convenience samples } \\
\hline Male subjects aged 15 to 45 years $^{42}$ & 3.4 & 2.0 & 0.3 & - & - & - & - & 6.0 & 1.4 \\
\hline Male participants of a community education programme ${ }^{43}$ & 1.7 & 15 & - & - & 5.6 & - & - & - & 0.4 \\
\hline Transport and industrial workers ${ }^{44}$ & 2.1 & - & 0.8 to 4.4 & - & - & - & - & - & - \\
\hline \multicolumn{10}{|l|}{ Facility based } \\
\hline STD clinic patients ${ }^{45-52}$ & 8.5 to 25.9 & 20.0 to 30.0 & 12.6 to 57.0 & 16.1 to 34.7 & - & 3.0 to 14.9 & 4.9 to 14.3 & - & 2.0 to 7.4 \\
\hline STD clinic patients with genital ulcers ${ }^{53}$ & - & - & - & 33.0 & - & - & - & - & - \\
\hline Patients attending primary health care ${ }^{44}$ & - & - & 3.6 & - & - & - & - & - & - \\
\hline \multicolumn{10}{|l|}{ Specific groups } \\
\hline Spouses of women with candida and trichomonas ${ }^{54}$ & - & - & - & - & 60.6 & - & - & - & - \\
\hline
\end{tabular}

The male clients of sex workers are a similarly heterogeneous mixture, representing all socioeconomic strata of society. Studies and longitudinal behavioural surveillance survey (BSS) data that have examined the number of clients served by sex workers reported that they see, on average, three clients a day, ${ }^{14-17}$ although one study reported 10 to 12 a day. ${ }^{13}$ A study in Orissa found that $15 \%$ of men (urban and rural) reported payment for sex at some point in their lifetime, and other cross sectional studies have found between $8 \%$ and $29 \%$ of men have paid for sex. ${ }^{18}$ One common feature observed in all the studies is that men often go to sex workers in groups. ${ }^{19}$ Tamil Nadu BSS data (1996-2000) have shown a decrease in the percentage of truckers/helpers and male factory workers who report payment for sex in the past one year (from 38\% in 1996 to $18.3 \%$ in 2000 ; and from $7 \%$ to $2.4 \%$, respectively). The most recent round of the BSS included young men living in slums and young male students: $11 \%$ and $1.1 \%$, respectively, reported payment for sex in the past year. ${ }^{17}$

\section{Non-commercial, non-marital sex}

"General population" surveys have reported premarital sexual activity among $7-48 \%$ of male respondents and $3-10 \%$ of female respondents, ${ }^{18}{ }^{20-27}$ while among predominantly unmarried school and college students (mostly in urban centres) sexual activity is reported by $8-39 \%$ of male students and $1-20 \%$ of female students. ${ }^{28-36}$ Generally higher levels of premarital sexual activity for boys/men may be a reflection of their later age of marriage. Some have argued that premarital sex is not the norm, and that for the majority of people, their first sexual experience occurs within marriage. ${ }^{19}$ A recent population based survey in Orissa among over 2000 urban and rural men reported that $25 \%$ had sex before marriage, and the overall mean age at first sex was 23 years. ${ }^{18}$ Men have a wide variety of premarital sex partners including sex workers, friends, relatives, and future spouses. ${ }^{18} 20-222526303137$ Among girls, reported premarital sexual contact is mainly with future spouses, friends, and relatives. ${ }^{21} 31$

A few studies have looked at the extent of non-spousal sex among married people in the general population and found relatively low reported levels: $2-6 \%$ of women and $4-12 \%$ of men. ${ }^{18} 202125263138$ While extramarital sex with friends and relatives has been reported, some studies suggest that men often pay for extramarital sex. Small scale studies among groups such as STI clinic patients and truck drivers have reported higher levels (81-98\%) of premarital and extramarital sexual experience. ${ }^{38} 39$

\section{Male to male sexual activity in India}

Male to male sexual activity (MSM) has been described in India since the time of the Kama Sutra, but open discussion of MSM is not well tolerated. Recent research has concentrated on describing the practices, lifestyles, and cultures of MSM in
India, with the most recent Tamil Nadu BSS data (2000) reporting on prevalence of MSM in the past one year: $2 \%$ of factory workers, $5 \%$ of truckers/helpers, and $12 \%$ of young men residing in slums. ${ }^{17}$ Studies have found that most men reporting MSM are married, and they meet their sex partners in covert and discreet surroundings. ${ }^{40}{ }^{41}$ Most of the interviewees first had sex with another man/boy at a relatively young age and reported non-penetrative sex most commonly. Use of condoms is reported to be relatively infrequent, ${ }^{19}$ although $\mathrm{Khan}^{40}$ reported $15-20 \%$ of older men regularly used condoms, and the BSS survey found that over $60 \%$ of truckers/helpers and $40 \%$ of young men in slums used condoms during anal sex. ${ }^{17}$

\section{EPIDEMIOLOGY OF STIS AND HIV}

India displays a remarkable level of heterogeneity in all aspects, including the epidemiology of STIs and HIV. Such diversity is a reflection of the size of the country, the "phase" of the STI/HIV epidemic in any one place, the highly variable broader contextual factors influencing prevalence and incidence rates, and the ability of the health care system to record and respond to these rates. While HIV surveillance exists, there is no fully functioning STI surveillance system; thus predictions and estimates are made on the basis of ad hoc surveys, often among facility based or convenience samples. There are few systems for passive surveillance of STIs in operation, and even fewer longer term surveys in existence which might be able to show trends with time. Given this, it is difficult to describe an "Indian scenario" per se, or even to hypothesise about the "epidemic phase" of STIs that any one geographical area may be experiencing. Tables 1 and 2 summarise results of published surveys and studies of STI/HIV prevalence in India.

\section{Epidemiological diversity}

A lack of standardisation in laboratory criteria can influence rates reported, ${ }^{0}$ and studies cited do not use either comparable sampling methods or laboratory diagnostic tests. In the case of syphilis, for example, some studies report all rapid plasma reagin (RPR) positive cases, while others report only those confirmed by the Treponema pallidum haemagglutination assay (TPHA). Diagnosis of other pathogens, such as Chlamydia trachomatis, shows an even wider variation in methods. In many studies the laboratory methods used are either inadequately explained or are not detailed at all. Retaining this critical perspective on the published data is important for both understanding the current reported figures and designing future research and control programmes.

A close review of the epidemiology highlights the following points.

- Data on STI prevalence in men are lacking, especially men in the "general population"; we located only two surveys of 


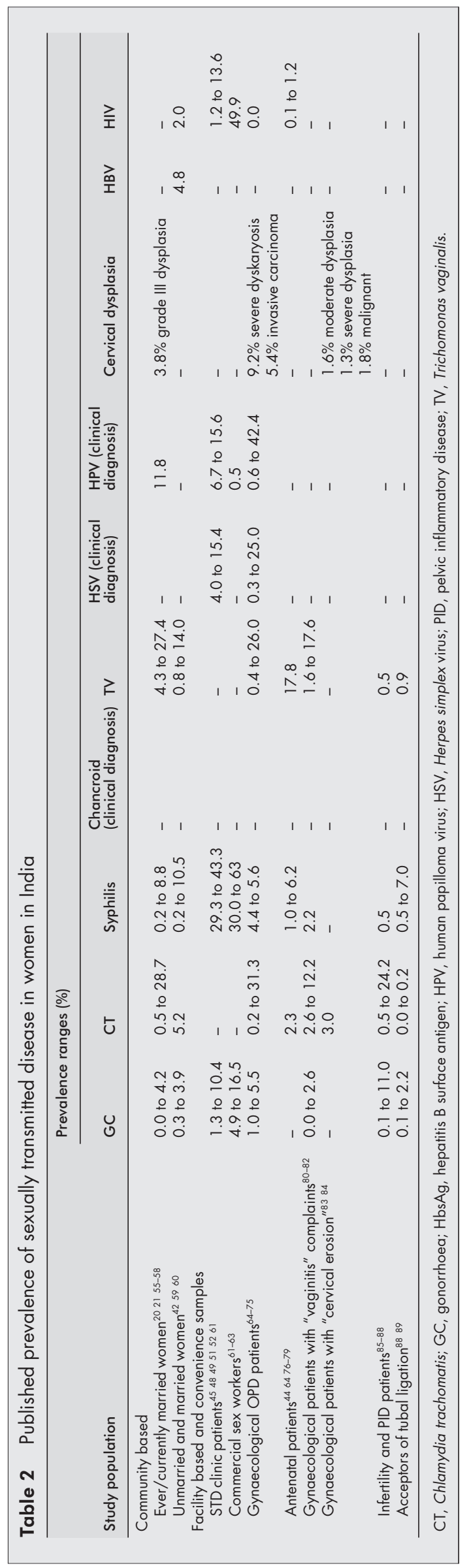

STIs in men in communities in India. The majority of facility based and community based studies have thus far focused on examining STI rates in women, and even these data are relatively patchy and incomplete.

- There are wide variations in both the reported prevalence of syphilis and diagnostic criteria used. Although variations in sample size and diagnostic procedures account for some of the differences, the high prevalence of syphilis among women in some parts of the country is in little doubt. Despite this, prevention of mother to child transmission of syphilis (through antenatal screening of all pregnant women) is unevenly implemented over the country.

- Little research has been carried out on the epidemiology of the viral infections (apart from HIV). Recent studies on hepatitis B infection found an average estimated carrier rate of $4 \%$ in the general population. ${ }^{91}$ With the major transmission route for this virus believed to be mother to child or childhood, researchers have recommended universal immunisation of neonates as the appropriate strategy for India. ${ }^{92}$ There are no community based seroepidemiological studies on the prevalence of antibodies to HSV-2.

- Cervical cancer contributes significantly to the burden of morbidity and mortality in Indian women, with an estimated 90000 new cervical cancer cases arising annually. Despite this, few data exist either on the prevalence of different types of cervical dysplasia among women, or on the number of women (and men) infected with human papilloma virus (HPV). Only one community based study among women in a Delhi slum has reported on the prevalence of HPV subtypes.

- Above all, there are remarkably few data reflecting trends of STIs with time. Therefore, the ability of policy makers and programme managers to select "phase appropriate" strategies ${ }^{93}$ is highly limited.

\section{HIV in India}

The first HIV positive person was identified in India in 1986, and there has since been a rapid spread of the epidemic in some parts of the country. Accurately estimating the number of HIV positive people is difficult, in part because of the wide national variation in factors which put people at risk. However, HIV surveillance has allowed policy makers and programme managers to monitor trends with time. As of June 2001, there had been a total of 24087 people diagnosed with AIDS and 98451 HIV positive people identified through HIV serosurveillance, ${ }^{94}$ and it is estimated that there are approximately 3.7 million HIV positive persons in India. Most infections have been acquired through sexual transmission $(80.8 \%)$, with $5.1 \%$ acquired through injecting drug use, $5.5 \%$ associated with blood or blood products, and less than $1 \%$ of cases infected through mother to child transmission. ${ }^{95}$

India has multiple epidemics of HIV in different geographical settings and among people with different types of risk. Initial cases were reported among female sex workers in the cities of Mumbai and Chennai, and injecting drug users in the north east of the country (especially in the state of Manipur ${ }^{96}$ where rates have risen dramatically). Since then, however, there has been a diffusion of the epidemic away from recognised "risk groups" and into the so called "general population" in some areas. In 1998, the estimated male:female ratio of HIV infection in India was approximately $1.8: 1 .^{97}$ Studies show that the number of cases in women infected through heterosexual transmission within marriage is increasing. Seroprevalences of 13-24\% HIV have been reported among female STD clinic patients who did not report themselves to be selling sex. ${ }^{61}{ }^{98-100}$ In addition, a number of small scale studies have reported that anywhere from $6 \%$ to $85 \%$ of wives of HIV infected intravenous drug users and STI clinic patients were HIV positive. ${ }^{101-103}$ Studies which have examined the prevalence of HIV infection in married women have found that 
husbands' reported behaviour was the major risk factor for many women. ${ }^{61} 99104105$

The seropositivity rate among pregnant women in selected sentinel sites ranges between zero and over 2\% (in the States of Maharashtra and Karnataka), and as high as 6\% in some slums in Mumbai. ${ }^{106} 107$

\section{Responses to risk and infection}

Despite the lack of a firm evidence base for both the epidemiology and the underlying risk factors for most of the STIs in India, policy makers and programme managers are nonetheless charged with designing and implementing programmes and interventions which are both effective and phase and context appropriate. The following sections explore what is known about the control of STIs from both the individual and programme level perspectives, and include a description of the health services in India.

\section{Individual level responses}

\section{Primary prevention of STIs: barrier methods}

Until 1996, India's strong family planning programme had method specific contraceptive targets. ${ }^{108}$ One outcome of a target driven approach has been the predominance of permanent contraceptive methods, and as a result the use of condoms is very limited. The 1998-9 National Family Health Survey (NFHS-2) reports that $48.2 \%$ of all married couples were using any (traditional or modern) method of contraception, which in $71 \%$ of cases was female sterilisation and in only $6.4 \%(3.1 \%$ of total population) was it condom use. ${ }^{109}$ The number of married couples who use condoms to prevent transmission of infection is not recorded.

The use, especially the consistent use, of condoms in non-marital sex is also reported to be very low. Studies among the "general" male population who reported non-marital sexual experience found that between $50 \%$ and $88 \%$ never used condoms during such encounters, with only $4-13 \%$ always using condoms during non-marital sexual liaisons. ${ }^{18} 212534$ Studies among groups at perceived or known higher risk (sex workers and their clients) have found a wide variation in rates of reported condom use, either at last sexual intercourse or over longer periods of time. ${ }^{61110111}$ For example, the Tamil Nadu BSS survey data have shown a rise in the percentage of sex workers and truckers/helpers who report condom use at last "non-regular" sex (from 56\% to $91 \%$ and from 44\% to 67\% between 1996 and 2000, respectively). Female factory workers and female students also report higher levels of condom use compared with five years ago, but among male factory workers and male students there has been a more recent decline in the percentages reporting condom use at most recent "non-regular" sex. ${ }^{17}$

Reported morbidity, health care seeking, compliance with treatment and partner communication

Much information on the prevalence of morbidity associated with STI/RTI (reproductive tract infection) in India comes from studies on self reported gynaecological morbidities. A series of six studies found that between 13\% and 57\% of women in the general population reported a current abnormal discharge. ${ }^{112}$ A large scale, population based survey of more than 2000 men in rural and urban Orissa found that the most common health concerns among men related to sexual health in general, and psychosexual concerns in particular. ${ }^{18}$ The poor correlation between self reported symptoms and laboratory confirmed infections ${ }^{113114}$ is compounded in India by the widely prevalent Ayurvedic belief system which equates discharge syndromes (dhatu loss) with loss of bodily power. Studies among both men and women have found a high prevalence of reported "abnormal discharge," but often with no biomedically defined cause for these symptoms. ${ }^{113} 115$

Treatment-seeking in India is determined by a number of variables, among which are: perceived seriousness and causal- ity of symptoms; availability and accessibility of health care; costs (including opportunity costs) of treatment; perceived and actual quality of care; and beliefs about the appropriate provider to consult. There is a strong and prevalent system of indigenous medical care in India and a multitude of different providers in the formal and informal sectors.

The proportion of symptomatic women who seek care is highly variable, ranging from a minority to a majority in different studies. ${ }^{20} 2^{5759}{ }^{116-121}$ Some symptomatic women may delay seeking treatment ${ }^{21}{ }^{121}$ : women in rural Tamil Nadu waited, on average, for a month before seeking any treatment. ${ }^{21}$ BSS data from Tamil Nadu have shown a relatively consistent percentage of men in different groups who report symptoms of urethritis in the past year, but while the percentage of symptomatic truckers who sought care from a qualified allopathic doctor has increased, it has correspondingly decreased among male factory workers and male students. Less than one in six of all symptomatic students had sought care from a qualified doctor. ${ }^{17}$

Other studies have found a variable proportion of symptomatic men who seek care. ${ }^{21}{ }^{27} 122123$ Even when men do seek care, the pattern of their treatment-seeking appears inadequate for a complete cure: one study ${ }^{124}$ reported that just over one third of patients completed the recommended treatment regimen and nearly one third had self treated with antibiotics before seeking treatment from STI clinics.

Communication between partners on sexual matters, including morbidity, is often restricted. Women are often, as noted by Ramasubban, ${ }^{125}$ "too afraid and confused to bring this [symptoms] to the notice of the family ..., both because they are not supposed to have such problems in the first place and also because they are socially deemed to be polluters, the originators of sexual problems." As a result, some studies have found that women do not inform their husbands about their gynaecological symptoms, ${ }^{21} 121126$ and a study among married women and men in rural Tamil Nadu reported that only slightly more than one third (37.3\%) of women with symptoms of possible reproductive tract infections, and one fifth $(19.9 \%)$ of the symptomatic male respondents informed their spouses about their illness experience. ${ }^{21}$ Moreover, communication was generally indirect, using symbolic expressions and gestures, thus leaving "informed" spouses to guess about their partners' illnesses.

\section{HEALTH SYSTEM RESPONSE TO STI}

\section{The public sector}

Public health in India has been a stated government priority since independence. Current spending in the broad health sector is $0.7 \%$ of $\mathrm{GNP}^{127}$ with a per capita health expenditure by central government of approximately \$US1 per annum. ${ }^{128}$ The share of central government expenditure spent on health and family welfare has remained at less than $2 \%$ of the total during the last decade. In contrast, the share of expenditure on debt interest payments has increased from $23.9 \%$ in 1991-2 to $29.9 \%$ in $2000-1$, and the share of defence expenditure out of the overall expenditure has risen from $14.7 \%$ in $1991-2$ to $17.3 \%$ in $2000-1 .{ }^{129}$

According to public health specialist Qadeer, India's pluralistic health system has undergone a series of changes as a result of both internal pressures (the demands of the growing middle classes fostering the development of private services, for example), and external forces (the donor driven policies of the 1990 s, for example). ${ }^{130}$ While primary health care services have always been intended to be relatively comprehensive in scope and coverage, the reality of service delivery in India has varied according to the perceived competing demands of national priorities. Thus for most of the 1970s and 1980s, much of the reproductive health service delivery was directed at achieving family planning targets. However, the Government's commitment to policy change following the International Conference on Population and Development in 1994 
and the 1995 Beijing Women's Conference has recently resulted in a move towards the provision of comprehensive integrated reproductive health care at all levels of the health sector. ${ }^{131}$ "Client centred, demand driven, high quality, integrated services" ${ }^{\prime 132}$ are the principles guiding service delivery. Public health services are free at the point of delivery, although patients usually have to pay for drugs and diagnostic services.

\section{The private sector}

In recent years the already prolific private sector has expanded in India. This sector includes a widespread system of indigenous medical practitioners. The importance of the private sector is highlighted with the official estimate that only $5-10 \%$ of patients (across all economic classes) with STIs present to public sector care. ${ }^{106}$ Despite the size and complexity of the private sector in India, its functions, motivations, and general structure are relatively poorly understood and documented. However, in allopathic medicine at least there are integral links between the public and private sectors. Both are often staffed by the same practitioners-a survey of 258 physicians in New Delhi found that among those employed in the public sector, $81 \%$ also worked in private practice. ${ }^{133}$ Patients attending public sector services may find themselves referred to the private sector for diagnostic services, "second opinions," or services not offered by providers in their public sector guise.

The private sector is currently largely unregulated and is not subject to safeguards that exist within the public sector (assuring access to services, for example). Most of the services are curative: the private sector is rarely involved in prevention of illness, but one recent exception has been the growth in the "social" marketing of condoms. Moves are under way to try and implement some degree of control and ensure standardisation of service delivery, but, as in many countries, the exact mechanisms for achieving this are not clear. One of the difficulties in achieving regulation within the private sector is the relative stakeholder strength. The allopathic private sector has grown considerably in the recent past, and the ability of the state to exert control over this sector is increasingly questioned. One possible procedure for increased state regulation which is now being discussed is to develop public-private collaboration through, for example, the government subcontracting services from the private sector. However, the ability of the state to be both partner and regulator of the private sector remains unclear.

\section{The NGO sector}

The not-for-profit NGO (non-governmental organisation) sector in India plays an influential and important role in many of the social sectors. In health, there is a predominance of NGO activity in the delivery of interventions in the field of reproductive health in general, and HIV/AIDS in particular. The programmes initiated by NGOs tend to have a greater degree of flexibility and more opportunities for innovation than can be provided in the public sector. The NGO scene ranges from small grass roots organisations working in defined locations to large scale institutions with multiple sites and target populations.

\section{STD/HIV PREVENTION AND CONTROL PROGRAMMES}

A national STD control programme has been in operation since 1946. The main objectives of the current programme are to reduce STD cases and thereby control HIV transmission, and to prevent short term and long term morbidity and mortality from STDs. ${ }^{106}$ Programme highlights include the following areas.

\section{Surveillance activities}

HIV surveillance began in 1985 with screening of blood from "high risk groups" in two cities. Sentinel surveillance was introduced in 1993. AIDS case surveillance is an important component of the surveillance activities and all medical institutions are required to report suspected AIDS cases, and referral institutions report all identified patients, to the National AIDS Control Organisation.

STD surveillance through syndrome based reporting from peripheral health institutions and aetiological information from STD clinics is due to be introduced. Behavioural surveillance has recently been incorporated into HIV surveillance activities, and baseline surveys are currently under way in various settings. The first wave of behavioural surveillance surveys in India was launched in Tamil Nadu in 1996 and was followed up by successive surveys (five rounds so far in Tamil Nadu) to observe trends in high risk behaviour among selected subpopulation groups such as female sex workers, truck drivers and helpers, male and female factory workers, and students. ${ }^{17}$ Similar surveys are now under way in other states.

\section{STD case management}

The main strategy aimed at achieving effective management for people with established infections has been to integrate STD services into the existing health care system, with a special emphasis on integration at the primary health care (PHC) level. Syndromic management is recommended by the National AIDS Control Organisation (NACO) for case management at this level. ${ }^{106}$ The effectiveness of syndromic management in women is currently under debate. ${ }^{134}{ }^{135}$ Recent reviews of the effectiveness of syndromic management found only one such study from India. ${ }^{136}{ }^{137}$ This was carried out in New Delhi among over 300 symptomatic women seeking care in an NGO reproductive health clinic. ${ }^{80}$ The STI prevalence in this clinic population was reasonably high with $22 \%$ of women having an STI (chlamydia, trichomonas, or syphilis; none with gonorrhoea) diagnosed in the laboratory, including 12\% with Chlamydia trachomatis. As with other studies, the recommended syndromic flow charts performed well for the management of vaginal infections, but the STIs were poorly managed, with only $5 \%$ of women infected with chlamydia receiving appropriate treatment.

Quality of care in public sector services is a current programme priority. However, moving beyond rhetoric to actually implementing change has not yet been noticeably achieved in many parts of the country. ${ }^{138}$ Studies in STD clinics have found that the quality of case management, especially counselling for prevention, is inadequate and poor. ${ }^{139-141}$ Observations of STD consultations in Madras revealed that advice on condom use was given during only $30 \%$ of the consultations. Instructions on how to use condoms were imparted to $6 \%$ of the clients, and condoms were provided to $1 \% .{ }^{139}$ Similarly, in one Tamil Nadu study only $15 \%$ and $28 \%$ of the symptomatic women and men, respectively, who had sought treatment from a health care facility were informed by the providers about the cause of their symptoms or the precautions to be taken to avoid the illness. ${ }^{21}$

Partner notification is a cornerstone of effective STI management, but studies in India have shown that this procedure is rarely discussed or initiated by health care providers. A clinic based study in Chennai ${ }^{139}$ observed that advice on partner notification was given during only $27 \%$ of the consultations. Likewise, a study in Delhi reported that none of the 100 male and female STD patients was advised about partner notification, ${ }^{140}$ and in a study in rural Tamil Nadu, none of the symptomatic women and only $5.7 \%$ of the symptomatic men were advised to have their spouses examined for a possible infection. ${ }^{21}$

Other public health control measures for STI control Aside from strengthening case management, the other pillars of public health interventions for STI control are implemented 
more patchily throughout the country. There has been a public sector syphilis screening programme for pregnant women since the 1950s; however, this is applied unsystematically and is further compromised by the fact that nationally only $57 \%$ of women receive antenatal care in the public sector. ${ }^{142}$ Even women seeking antenatal care are likely to only receive a limited range of services-less than half have their blood pressure checked, for example. ${ }^{143}$ In rural India, only $33.6 \%$ of births are attended by a health professional, ${ }^{109}$ and less than a quarter of births are in institutional settings, thus reducing the impact of prevention programmes for ophthalmia neonatorum for example.

Cervical cancer screening is another example of a programme that is only in its infancy. The absence of a nationwide screening programme means that many women do not present for care until the cancer is at an advanced stage (Institute of Cytology and Preventive Oncology, Indian Council for Medical Research, unpublished data). Establishing a screening programme is problematic in a setting where those women most at risk (that is, older women) are unlikely to attend public sector health care settings (which are predominantly for maternal and child health care).

\section{STI prevention and care outside the public sector}

Perhaps as a result of a stimulating and innovative NGO climate, this sector has some of the best known and potentially most successful interventions to slow the spread of STIs, including HIV, in groups at higher risk of infection. The types of intervention undertaken range from promotion of information, education, and communication (IEC) material, provision of health services, and home based care for people with HIV/AIDS. Possibly the best known is an intervention among sex workers in Calcutta. Known as "Sonagachi" (after the district in the city where many of the brothels are located), this intervention has become globally recognised for the innovative approach it has taken to risk reduction. Recognising that sexual behaviour is not determined by individual-led parameters alone, the intervention has sought to address a wide range of social, economic, health, and other concerns of the women working in the brothels, and includes activities targeted at male clients. The project is now run largely from within the brothel community, and has succeeded in a number of areas, increased literacy being one of the major achievements. HIV rates in women selling sex in the Sonagachi area have remained relatively stable, and are currently around 5\%. Rates of other STIs have fallen during the lifetime of the project. ${ }^{143}$ These figures compare, for example, with data from Mumbai, which showed an increase in HIV prevalence in female commercial sex workers from $21.1 \%$ to $71 \%$ over the period 1990 to $1997 .{ }^{144}$

Other targeted interventions carried out with the assistance of NGOs have concentrated on reducing risks for injecting drug users and people working along highways (truck drivers and their assistants, for example). Injecting drug use has been a significant problem in India's north east states (bordering Myanmar), and HIV rates among injecting drug users are currently over $80 \%$. Once thought to be a relatively contained problem, injecting drug use (especially of buprenorphine) is currently thought to be on the increase throughout the country (Panda S, personal communication).

\section{Voluntary HIV counselling and testing}

The Government of India's policy statement on HIV testing emphasises that no individual should undergo mandatory testing for HIV, adequate voluntary testing facilities with preand post-test counselling should be made available throughout the country, and there should be at least one government run HIV testing centre per district. ${ }^{145}$ To implement these objectives, the public sector has been collaborating with NGOs that have taken the lead in developing anonymous HIV counselling and testing centres.

\section{Care for people living with HIV/AIDS}

As the absolute number of people living with HIV/AIDS increases, provision of health care and social support to people living with HIV/AIDS has become a more pressing issue, and has been adopted as an integral component of the national AIDS prevention and control policy. The measures taken by the government to meet the growing needs for care and support of people living with HIV/AIDS (PLWHAs) include: provision of drugs, free of charge, for the management of opportunistic infections in patients at government health care settings; counselling services for HIV infected people; and supporting NGOs and community based organisations in providing hospice care. Nonetheless, isolation, stigmatisation, and other forms of discrimination characterise the experience of the vast majority of PLWHAs in India and pose severe constraints on people revealing their HIV/AIDS status and availing health care and support. Compounding these problems is the high cost of most treatment options. Although antiretroviral drugs are currently produced by Indian pharmaceutical companies and sold at prices well below those in industrialised countries, only 3-5\% of the known HIV infected individuals are currently able to afford such treatment in India. ${ }^{146}$

\section{EXPENDITURE FOR STI/HIV PREVENTION AND CARE} Expenditure in one state

A recent survey undertaken among a random selection of 1100 households in and around the city of Udaipur (Rajasthan) looked at household level expenditures on reproductive and child health. ${ }^{147}$ The State of Rajasthan spends a total of $6 \%$ of its GDP on health care, of which just over $21 \%$ is spent on reproductive and child health services. The largest source of financing for health care in Rajasthan comes from household (out-of-pocket) expenditure-71\% of the total spent on health, and a total of $80 \%$ of expenditure in the reproductive and child health sector. In Rajasthan, "RTI [reproductive tract infection] services" constitute the third leading use of public sector (government and donor) funds in reproductive and child health, but the top expenditure for households in their purchase of all types of reproductive and child care. Thus families surveyed spent more of their own money on seeking care for symptoms (not aetiologically proven) of reproductive tract infections than they spent on child health care, and all forms of safe motherhood (pre- and postnatal, obstetric, and abortion services).

\section{Expenditure nationally}

Funding for the HIV/AIDS programme comes from a variety of sources, including central Government and multilateral and bilateral donors. During the 1990s the major expenditures of the HIV/AIDS control programme were in promoting IEC activities and in ensuring blood safety. The year 1998-99 witnessed an increased financial allocation, but utilisation of funds has been suboptimal until very recently. For example, only around $50 \%$ of the total allocation for HIV/AIDS control was used during 1992-5. ${ }^{106}$

Clinical management of people with HIV/AIDS and surveillance for these infections currently receive less than one sixth of the AIDS control programme budget. This figure may be expected to rise in the future: not only will the number of people requiring clinical care increase, but the local cost of patented drugs may rise when India's patent regime becomes Trade Related Intellectual Property Rights (TRIPS) compliant in 2005. At present the current cost of locally produced fluconazole in India is $\$ 55$ for 100 tablets, compared to $\$ 697$ in Malaysia, and $\$ 817$ in the Philippines. ${ }^{148}$

\section{CONCLUSIONS}

India, united through many aspects, displays remarkable diversity-something that is apparent from even a cursory 
review of the known epidemiology of STIs in the country. It is hard to overestimate the scale of the challenge faced by policy makers and programme managers charged with designing effective, accessible, and affordable programmes for STI control in the country. As such, it is important to realise that there is no "Indian scenario" of sexually transmitted infections, including HIV, per se. Instead there is a complex interplay and overlap of different STI/HIV epidemics at different stages of development, with varied underlying causes. One of the strongest challenges to the design of appropriate prevention and intervention strategies in the absence of longitudinal data is that there is no indication as to where on an epidemic curve any cross sectional results should be placed. Is STI prevalence rising or falling? Are current patterns of sexual behaviour changing or staying constant? Are interventions needed more in one geographical location than another? These, and other fundamental questions forming the basis of evidence based health care planning, are often left unanswered when programmes are designed.

As we have seen in detail throughout this paper, there are many features that make this a vulnerable country as far as an STI/HIV epidemic is concerned. These include the lack of a strong evidence base on which to formulate decision making, a pluralistic and often unregulated health sector, and a highly vulnerable population. Nonetheless, India has shown strong commitment to other areas of a comprehensive reproductive health care programme, and may be able to do so in the field of STI/HIV control. Vast numbers of people in India are severely disadvantaged in terms of income, education, power structures, and gender. Addressing these basic issues of human rights lies at the core of achieving better health outcomes $^{149}$ (including reproductive and infectious diseases) in India. Such a challenge is formidable in terms of its required scope and coverage, but lies at the heart of improving sexual health for the greatest number of people in India.

\section{Authors' affiliations}

S Hawkes, Clinical Research Unit, London School of Hygiene \& Tropical Medicine, London, UK

K G Santhya, Population Council India, New Delhi, India

\section{REFERENCES}

1 Irwig L, Zwarenstein $M, Z$ wi $A B$, et al. A flow diagram to facilitate selection of interventions and research for health care. Bull WHO 1998:76:17-24.

2 International Institute for Population Sciences. National family health survey (MCH and family planning), India 1992-93. Bombay: IIPS, 1995

3 Registrar General and Census Commissioner, India (2001): http://www.censusindia.net

4 Srinivasan K. An overview of demographic transition in India since 1970. In: Srinivasan K, ed. Population policy and reproductive health New Delhi: Hindustan Publishing Corporation, 1996:3-66.

5 Jetley S. Impact of male migration on rural females. Economic and Political Weekly 1987;22:WS47-53.

6 Ramasubban R. Sexual behaviour and conditions of health care: potential risks for HIV transmission in India. In: Dyson T, ed. Sexual behaviour and networking: anthropological and socio-cultural studies on the transmission of HIV Liege: Derouaux-Ordina, 1992:175-202.

7 Ainsworth M, Fransen L, Over M. Confronting AIDS: evidence from the developing world. Luxembourg: The European Commission and the World Bank, 1998

8 United Nations Development Programme. Human development report 1999. New York: Oxford University Press, 1999.

9 United Nations Children's Fund. The state of the world's children 1999. New Delhi: Model Press, 1999.

10 Ministry of Health and Family Welfare, 2000: http://mohfw.nic.in/ helindi.html

11 World Bank. World development report: investing in health. New York: Oxford University Press, 1993.

12 Nag M. Sexual behaviour and AIDS in India. New Delhi: Vikas Publishing House Private Ltd, 1996.

13 National AIDS Control Organisation. A summary of the findings of the high risk behaviour study from 18 cities. New Delhi: Government of India, Ministry of Health and Family Welfare, NACO, 1997.
14 Ghosh M. Das NK. Anonder Opekshay: Chondalika Ekdal Khokkosh [in Bengali]. Calcutta: Calcutta Development Dialogue, 1990; cited in: Nag M. Sexual behaviour and AIDS in India. New Delhi: Vikas Publishing House Private Ltd, 1996

15 Jana S. Untitled abstract published in the 2nd International Congress on AIDS in Asia and the Pacific, Randwick, Australia (AIDS Society of Asia and the Pacific), 1992:105; cited in: Nag M. Sexual behaviour and AIDS in India. New Delhi: Vikas Publishing House Private Ltd, 1996.

16 Jana S. Three years stint at Sonagachi: an exposition. Paper distributed at the Indo-US workshop on behavioural research priorities: Developing Effective Strategies for the Prevention of HIV in India. Tata Institute of Social Sciences, Mumbai, 24-29 April 1995; cited in: Nag M. Sexual behaviour and AIDS in India. New Delhi: Vikas Publishing House Private Ltd, 1996.

17 AIDS Prevention and Control Project (APAC). HIV risk behaviour surveillance survey in Tamil Nadu - report on the fifth wave. Chennai: APAC and USAID, 2001

18 Collumbien M, Das B, Bohidar N, et al. Male sexual behaviour in Orissa. Paper presented at the Workshop on Reproductive Health in India: New Evidence and Issues. Pune, 28 February-1 March 2000.

19 Pelto PJ, Joshi A, Verma R. Development of sexuality and sexual behaviour among indian males: implications for the reproductive health programme. New Delhi: Population Council, 2000

20 Prasad JH, George V, Lalitha MK, et al. Prevalence of reproductive trac infection among adolescents in a rural community in Tamil Nadu. Paper presented at the Workshop on Reproductive Health in India: New Evidence and Issues. Pune, 28 February-1 March 2000.

21 Santhya KG. Factors affecting reproductive tract infections in Southern India. Flinders University, South Australia, 1999. [Unpublished thesis.]

22 Savara $M$, Sridhar CR. Sexual behaviour of urban, educated Indian men: results of a survey. J Family Welfare 1992;38:30-43.

23 Balaganesh G, Ramakrishnaiah Y, Rao SY, et al. A study on the awareness about AIDS/STD in Indian communities Indian J Sex Transm Dis 1993; 14:38-43.

24 Balachandar G, Raghavan SS, Rajaram P. Gynaecological problems in adolescents J Obstet Gynaecol India 1994:44:599-604.

25 Kumar A, Mehra M, Badhan SK, et al. Heterosexual behaviour and condom usage in an urban population of Delhi, India AIDS Care 1997;9:311-18.

26 Basu DP. Appropriate methodologies for studying sexual behaviour in India. Indian J Social Work 1994:55:573-88.

27 Carolina Population Center. Uttar Pradesh Male Reproductive Health Survey 1995-1996. North Carolina: Carolina Population Center, 1997 28 Rakesh A. Premarital sexual attitudes and behaviour among adolescent girls. Jaipur: Printwell, 1992.

29 Seghal VN, Sharma AK, Bhattacharya SN. KABP study on AIDS among school boys. Abstract published in the 2 nd International Congress on AIDS in Asia and the Pacific. Randwick, Australia: AIDS Society of Asia and the Pacific, 1992:192.

30 Goparaju L. Discourse and practice: rural-urban differences in male students' sexual behaviour in India. Paper prepared for the IUSSP seminar on sexual subcultures, migration and AIDS, Thailand, 27 February-3 March 1994; cited in: Nag M. Sexual behaviour and AIDS in India. New Delhi: Vikas Publishing House Private Ltd, 1996.

31 Savara M, Sridhar CR. Report on a survey of sexual behaviour patterns and attitudes amongst men and women in Maharashtra. Bombay: Shakti, 1994.

32 Kaur U, Sahni SP, Bambery P, et al. Sexual behaviour, drug use and hepatitis B infection in Chandigarh students. Natl Med J India 1996;9:156-9.

33 Rangaiyan G. Sexuality and sexual behaviour in the age of AIDS: a study among college youth in Bombay. Mumbai: International Institute for Population Sciences, 1996. [Thesis.]

34 Mathai R, Ross MW, Hira S. Concomitants of HIV/STD risk behaviours and intention to engage in risk behaviours in adolescents in India. AIDS Care 1997:9.563-76

35 Singh KK, Bloom SS, Tsui AO. Husbands' reproductive health knowledge, attitudes, and behaviour in Uttar Pradesh, India. Stud Family Plann 1998;29:388-99.

36 Suchdev P. Sex on campus: a preliminary study of knowledge, attitudes, and behaviour of university students in Delhi, India. J Biosoc Sci 1998; 30:95-105.

37 Sharma V, Sharma A. Adolescent boys in Gujarat, India: their sexual behaviour and their knowledge of acquired immunodeficiency syndrome and other sexually transmitted diseases. J Dev Behav Paediatr 1997; 18:399-404.

38 Narayan V. Venereal diseases: a social dilemma. New Delhi: Cosmo, 1984.

39 Rao A, Nag M, Mishra K, et al. Sexual behaviour patterns of truck drivers and their helpers in relation to female sex workers. Indian J Social Work 1994:55:603-15.

40 Khan S. Cultural contexts of sexual behaviour and identities and their impact upon preventive models: an overview of South Asian men who have sex with men. Indian J Social Work 1994;55:633-46.

41 Kulkarni V, Kulkarni S, Sahasrabudhe N, et al. Networks, language and sexual behaviours of men who have sex with men in an urban setting. Paper presented at the Workshop on Reproductive Health in India: New evidence and Issues. Pune, India, 28 February-1 March 2000.

42 AIDS Prevention and Control Project (APAC). Community prevalence of sexually transmitted diseases in Tamil Nadu 1998 - a report. Chennai: APAC, 1998. 
43 Bang AT, Bang RA, Baitule $M$, et al. High prevalence and wide spectrum of reproductive morbidities in males in Gadchiroli, India. [Undated and unpublished. Please contact corresponding author.]

44 Rowley J, Berkley S. Sexually transmitted diseases. In: Murray CJL, Lopez AD, eds. Health dimensions of sex and reproduction- the global burden of sexually transmitted diseases, HIV maternal conditions, perinatal disorders, and congenital anomalies. The Harvard School of Public Health, on behalf of WHO and World Bank. Boston: Harvard University Press, 1998.

45 Singh KG, Joshi MK, Bajaj AK. Pattern of sexually transmitted diseases in Allahabad Indian J Sex Transm Dis 1990;1 1:6-8.

46 Bhujwala RA, Mishra B, Bhargava NC, et al. Non-gonococcal urethritis in men and its response to therapy. Indian J Med Res 1984;79:728-32.

47 Sharma M, Nayak N, Malhotra S, et al. Chlamydiazyme test for rapid detection of Chlamyida trachomatis. Indian J Med Res 1989;89:4-1 1

48 Kamat HA, Banker DD. Human immunodeficiency virus-1 infection among patients with sexually transmitted diseases in Bombay. Natl Med J India 1993:6:11-13

49 Chopra A, Mittal RR, Singh P, et al. Patterns of sexually transmitted diseases at Patiala. Indian J Sex Transm Dis 1990;1 1:43-5.

50 Risbud A, Chan-Tack K, Gadkari D, et al. The etiology of genital ulcer disease by multiplex polymerase chain reaction and relationship to HIV infection among patients attending sexually transmitted disease clinics in Pune, India. Sex Transm Dis 1999;26:55-62.

51 Chaudhary SD, Bhattia KK, Bansal RK, et al. Pattern of sexually transmitted diseases in Rohtak. Indian J Sex Transm Dis 1988;9:4-7.

52 George S, Jacob M, John TJ, et al. A case-control analysis of risk factors in HIV transmission in South India. J Acqu Immune Defic Syndr Hum Retrovirol 1997; 14:290-3.

53 Kumar V, Garg BR, Baruah MC. A clinical study of genital ulcers. Indian J Sex Transm Dis 1990;11:15-18.

54 Kumar $\mathbf{P}$, Sharma NK, Sharma U, et al. Trichomoniasis and candidiasis in consorts of females with vaginal discharge. Indian J Sex Transm Dis 1990;11:54-6.

55 Garg S, Sharma N, Bhalla P, et al. Reproductive morbidity in an Indian urban slum: need for health action. Paper presented at the Workshop on Reproductive Health in India: New Evidence and Issues. Pune, 28 February-1 March 2000

56 Bhatia JC, Cleland J, Bhagavan L, et al. Levels and determinants of gynaecological morbidity in a district of south India. Stud Family Plann 1997;28:95-103.

57 Parikh I, Taskar V, Dharap N, et al. Gynaecological morbidity among women in a Bombay slum. [Unpublished report; undated. Please contact corresponding author]

58 Chhabra S, Swarup G, Swarup K, et al. Correlation of cervical abnormalities with abnormal smears in mass screening programme of cervical cytology. J Obstet Gynaecol India 1991;41:681-3.

59 Bang R, Bang AT, Baitule $M$, et al. High prevalence of gynaecological diseases in rural Indian women. Lancet 1989;i:85-7.

60 Oomman N. Poverty and pathology: comparing rural Rajasthani women's ethnomedical models with biomedical models of reproductive morbidity: implications for women's health in India. Baltimore: Johns Hopkins University, 1996. [PhD thesis.]

61 Gangakhedkar RR, Bentley ME, Divekar AD, et al. Spread of HIV infection in married monogamous women in India. JAMA 1997;278:2090-2

62 Jana S, Bandyopadhyay N, Mukherjee S, et al. STD/HIV intervention with sex workers in West Bengal, India. AIDS 1998;12(suppl B):S101-8.

63 Urmil AC, Dutta PK, Basappa K, et al. A study of morbidity pattern among prostitutes attending a municipal clinic in Pune. J Indian Med Assoc 1989;87:29-31.

64 Pal A, Ghosh UK, Ganguli G, et al. Socio-demographic profile of sexually transmitted diseases in females. J Obstet Gynaecol India 1993:43:388-90.

65 Chaudhuri $\mathbf{P}$, lyengar R. Chlamydia trachomatis infection in a south Indian population - a prospective pilot study. J Obstet Gynaecol India 1994;44:593-4

66 Bhatnagar P, Kashyap V, Das DK, et al. Clinico-epidemiological study of condylomatous lesions in inflammatory smears. J Obstet Gynaecol India 1991:41:793-8.

67 Dhall K, Sarkar A, Sokhey C, et al. Incidence of gonococcal infection and its clinicopathological correlation in patients attending gynaecological out patient department. J Obstet Gynaecol India 1990;40:410-13

68 Parashari A, Singh V, Sodhani P, et al. Clinical and aetiological profile of reproductive tract infections (RTIs) among women attending gynaecology out-patient department of a major city hospital in Delhi. $J$ Obstet Gynaecol India 1994;44:790-7.

69 Misra JS, Das K, Tandon P, et al. Sexually transmitted pathogens and cervical carcinogenesis. J Obstet Gynaecol India 1992:42:380-3.

70 Joshi JV, Palayekar S, Hazari KT, et al. The prevalence of chlamydia trachomatis in young women. Natl Med J India 1994;7:57-9.

71 Mali JJ-B, Hazari K, Chitlange S, Shah R. Abnormal cytology indicating sexually transmitted diseases in women attending family welfare clinics. J Obstet Gynaecol India 1991:41:521-4.

72 Gogate A, Deodhar L, Bhatt R, et al. Mycoplasma hominis infections in female genital tract and use of immunofluoroscence for antibody detection Indian J Med Res 1990;91:364-7

73 Jayarao P, Gogate A, Deodhar L, et al. Trichomoniasis: a clinical and laboratory evaluation. J Obstet Gynaecol India 1989;39:829-33.

74 Mishra D, Singh G, Sharma D. Unsuspected gonococcal infection, candidiasis and trichomoniasis in females. Indian J Sex Transm Dis 1988;9:25-8.
75 Sinha G. The prevalence of wart virus infection and its asociation with pre-malignant lesions of the cervix. J Obstet Gynaecol India 1994;44:931-5

76 Singh NGB, Devi YL, Singh HL, et al. Incidence of HIV (human immunodeficiency virus) infection and VDRL reactivity among pregnant women. J Obstet Gynaecol India 1992;42:576-80.

77 Hira SK. Guidelines for prevention of adverse outcomes of pregnancy due to syphilis. Geneva: World Health Organisation, 1991.

78 Kunte A, Misra V, Paranjape R, et al. HIV seroprevalence and awareness about AIDS among pregnant women in rural areas of Pune district, Maharashtra, India. Indian J Med Res 1999;110:115-22.

79 Gupta MK, Thergaonkar WP, Chawla N. Anonymous testing of HIV infection in pregnant women. J Commun Dis 1998;30:121-2

80 Vishwanath S, Talwar V, Prasad R, et al. The assessment and management of vaginal discharge - a study among symptomatic women in a family planning clinic in East Delhi. New Delhi: Population Council, 1998.

81 Deb M, Kaur TP, Prakash K, et al. Incidence of Gardnerella vaginalis in non specific vaginitis. J Obstet Gynaecol India 1989;39:88-92.

82 Pandit DV, Bhatt RR, Karnad JM, et al. Microbial screening of females with vaginitis. J Obstet Gynaecol India 1993:43:244-7.

83 Chhabra S, Aher K, Narang P, et al. Chlamydia trachomatis infection and cervical intraepithelial neoplasia. J Obstet Gynaecol India 1993;43:93-4

84 Kar J, Agarwal PL, Mishra SD, et al. Vaginal cytology in erosion of cervix and cervicitis. J Obstet Gynaecol India 1988;38:100-5.

85 Bhujwala RA, Biswas TD, Bhargava $\mathrm{V}$, et al. Detection of chlamydial and gonococcal antibodies in women with pelvic inflammatory disease and infertility - an aid to diagnosis. J Obstet Gynaecol India 1988;38:96-9

86 Chhabra S, Fali L. Clinical genital infection in infertile women with Chlamydia trachomatis infection. J Obstet Gynaecol India 1992;42:68-70.

87 Kushtagi P, Rao K, Abraham E, et al. Prevalence of antibodies to Chlamydia trachomatis among infertile couples. J Obstet Gynaecol India 1991:41:671-3.

88 Brabin L, Gogate A, Gogate S, et al. Karande A, Khanna R, Dollimore $\mathrm{N}$, deKoning K, Nicholas S, Hart CA. Reproductive tract infections, gynaecological morbidity and HIV seroprevalence among women in Mumbai, India. Bull WHO 1998;76:277-87.

89 Char A, Vaidya S. Gynaecological morbidity among women seeking sterilization services in rural Maharashtra. Paper presented at the Workshop on Reproductive Health in India: New Evidence and Issues. Pune: 28 February-1 March 2000

90 Bulut A, Yolsa N, Filippi V, et al. In search of truth: comparing alternative sources of information on reproductive tract infection. Reprod Health Matters 1995;6:31-9.

91 Tandon BN, Acharya SK, Tandon A. Epidemiology of hepatitis B virus infection in India. Gut 1996;38(suppl 2):S56-9

92 Aggarwal R, Naik SR. Prevention of hepatitis B infection: the appropriate strategy for India. Natl Med J India 1994;7:216-20.

93 Wasserheit JN, Aral SO. The dynamic topology of sexually transmitted disease epidemics: implications for prevention strategies. J Infect Dis 1996; 174(suppl 2):S201-13.

94 National AIDS Control Organisation, 2001: http:// www.naco.nic.in/vsnaco/indianscene/overv.htm

95 National AIDS Control Organisation, 2000: http:// www.naco.nic.in/vsnaco/indianscene/update.htm, (date 07/09/00)

96 Pal SC, Sarkar S, Naik TN, et al. Explosive epidemic of HIV infection in north-eastern states of India, Manipur and Nagaland. (Indian Council for Medical Research) CARC Calling 1990;3:2-6.

97 National AIDS Control Organisation, 2000: http:// www.naco.nic.in/vsnaco/indianscene/update.html\#7

98 Rodrigues JJ, Mehendale SM, Shepherd ME, et al. Risk factors for HIV infection in people attending clinics for sexually transmitted diseases in India. BM 1995:311:283-6.

99 Mehendale SM, Shepherd ME, Divekar AD, et al. Evidence for high prevalence and rapid transmission of HIV among individuals attending STD clinics in Pune, India. Indian J Med Res 1996;104:327-35.

100 Divekar AA, Gogate AS, Shivkar LK, et al. Disease prevalence in women attending the STD clinic in Mumbai (formerly Bombay), India. Int J STD AIDS 2000; 11:45-8.

101 Mathai R, Prasad PVS, Jacob M, et al. HIV seropositivity among patients with sexually transmitted diseases in Vellore. Indian J Med Res 1990:91:239-41.

102 Mohamed M, Ravinathan R, Johnson M et al. HIV transmission among the married women San Francisco: Vlth International Conference on AIDS, 23-24 June 1990;6:415 [abstract 3053].

103 Sarkar S, Panda S, Das N, et al. Rapid spread of HIV among injecting drug users of north-eastern India. CARC Calling 1993;6:23-8.

104 John TJ, Bhushan N, Babu PG, et al. Prevalence of HIV infection in pregnant women in Vellore region. Indian J Med Res 1993;97:227-30.

105 Jacob M, John TJ, George S, et al. Increasing prevalence of human immunodeficiency virus infection among patients attending a clinic for sexually transmitted diseases. Indian J Med Res 1995;101:6-9.

106 National AIDS Control Organisation. Country scenario 1997-98. New Delhi: Ministry of Health and Family Welfare, 1998

107 National AIDS Control Organization, 2000: http:// www.naco.nic.in/vsnaco/indianscene/indscen.htm

108 Pachauri S. Moving towards reproductive health: issues and evidence. In: Pachauri S, ed. Implementing a reproductive health agenda in India: the beginning. New Delhi: Population Council, 1999:xiii-xlvii. 
109 International Institute for Population Sciences and ORC Macro. National family health survey (NFHS-2), 1998-99, India. Mumbai: IIPS 2000

110 Asthana S, Oosvogels R. Community participation in HIV prevention: problem and prospects for community-based strategies among female sex workers in Madras. Soc Sci Med 1996:43:133-48.

111 Mishra R. STDs and HIV/AIDS: a KAP study among drug operators. Health for the Millions 1998;Sept-Oct: $11-13$

112 Koenig M, Jejeebhoy S, Singh S, et al. Undertaking community-based research on the prevalence of gynecological morbidity: lessons from India. Paper presented at the IUSSP seminar on innovative approaches to the assessment of reproductive health. Manila: 24-27 September 1996.

113 Trollope-Kumar K. Cultural and biomedical meaning of the complaint of leukorrhea in South Asian women. Trop Med Int Health $2001 ; 6: 260-6$

114 Elias C, Low NM, Hawkes S. Clinical definitions of gynaecological morbidity relating to infections of the reproductive tract. In: Jejeebhoy $\mathrm{S}$, Koenig M, Shah I, eds. Undertaking community surveys of gynaecological morbidity. WHO 2002 (in press).

115 Lambert H. Methods and meanings in anthropological, epidemiological and clinical encounters: the case of sexually transmitted diseases and HIV control and prevention in India. Trop Med Int Health 1998;3:1002-10.

116 Ravindran TKS. Women's health situation in a rural poor population in Chengalpattu, Tamil Nadu. In: DasGupta M, Chen LC, Krishnan TN, eds. Women's health in India - risk and vulnerabilities. Bombay: Oxford University Press, 1995: 175-211

117 Barua A. Reproductive health needs of married adolescent girls in rural Maharashtra. Paper presented at the Workshop on Reproductive Health in India: New Evidence and Issues. Pune: 28 February-1 March 2000.

118 Bhatia JC, Cleland J. Perceived gynaecological morbidity, health seeking behaviour and expenditure in Karnataka, India. Paper presented at the Workshop on Reproductive Health in India: New Evidence and Issues. Pune: 28 February-1 March 2000

119 Joshi A, Dhapola M, Pelto PJ. Gynaecological problems: perceptions and treatment seeking behaviours of rural Gujarati women. Paper presented at the Workshop on Reproductive Health in India: New Evidence and Issues. Pune: 28 February-1 March 2000

120 Oomman N. Poverty and pathology: Rajasthani women's perceptions of gynaecological morbidity and their implications for research and prevention. Paper presented at the Workshop on Reproductive Health in India: New Evidence and Issues. Pune: 28 February-1 March 2000

121 Ramasubban R, Rishyasringa B. Treatment seeking by women in Mumbai slums. Paper presented at the Workshop on Reproductive Health in India: New Evidence and Issues. Pune: 28 February-1 March 2000.

122 Verma RK, Rangaiyan G, Sharma S, et al. A study of sexual health problems and treatment seeking behaviour among men in a slum community. Paper presented at the Workshop on Reproductive Health in India: New Evidence and Issues. Pune: 28 February-1 March 2000

123 Joseph A, Srikanth RA, Abraham S, et al. Sexual behaviour: older husbands younger wives. Paper presented at the workshop on men as supportive partners in reproductive and sexual health. Kathmandu: 23-26 June 1998.

124 Ganguli DD, Ramesh V, Zaheer SA, et al. Profile of gonorrhoea in males. Indian J Sex Transm Dis 1985:6:44-6.

125 Ramasubban R. Patriarchy and the risks of STD and HIV transmission to women. In: DasGupta M, Chen LC, Krishnan TN, eds. Women's health in India - risk and vulnerabilities. Bombay: Oxford University Press, 1995:212-41.

126 Bang R, Bang A. Women's perception of white vaginal discharge: ethnographic data from rural Maharashtra. In: Gittelsohn J, Bentley ME,
Pelto $\mathrm{PJ}$, et al, eds. Listening to women talk about their health issues and evidence from India. New Delhi: Har-Anand Publications for the Ford Foundation, 1994:79-94.

127 United Nations Development Programme. Human development report 1999. New York: Oxford University Press, 1999.

128 World Bank. Project appraisal document on a proposed credit in the amount of SDR 140.82 million to India for a second national HIV/AIDS control project. World Bank Report No 18918-IN. Health, Nutrition and Population Sector Unit, South Asia region, 1999.

129 Economic and Political Weekly Research Foundation. Finances of government of India. Economic and Political Weekly 2000;35:1302-24

130 Qadeer I. Health care systems in transition III. India, part I. The Indian experience J Public Health Med 2000;22:25-32

131 Pachauri S. Defining a reproductive health package for India: a proposed framework. New Delhi: The Population Council, 1995.

132 Ministry of Health and Family Welfare. India's progress towards reproductive health goals (ICPD +5). New Delhi: Ministry of Health and Family Welfare, 1999.

133 Chawla M. Dual job-holding by public sector physicians in India. Boston: Harvard School of Public Health, 1996.

134 Dallabetta GA, Gerbase AC, Holmes KK. Problems, solutions, and challenges in syndromic management of sexually transmitted diseases. Sex Transm Inf 1998;74(suppl 1):S1-11.

135 Hawkes S, Morison L, Foster S, et al. Managing RTIs in women in low prevalence, low income situations; an evaluation of syndromic management in Matlab, Bangladesh. Lancet 1999;354:1776-81.

136 Sloan NL, Winikoff B, Haberland N, et al. Screening and syndromic approaches to identify gonorrhoea and chlamydial infections among women. Stud Family Planning 2000;31:55-68.

137 Hawkes S, Lee-Jones L, Morison L. The costs of syndromic management in different settings. Draft report to UNAIDS, 2000. [Unpublished. Please contact corresponding author].

138 Koenig MA, Khan ME. Improving quality of care in India's family welfare programme: the challenge ahead. New York: Population Council, 1999

139 Mertens TE, Smith GD, Kantharaj K, et al. Observations of sexually transmitted disease consultations in India. Public Health 1998;11:123-8.

140 Roy V, Bhargava P, Bapna JS, et al. Treatment seeking behaviour in sexually transmitted diseases. Indian J Public Health 1998;42:133-5.

141 Nataraj S. Waiting for a connection. Populi 1994;21:6-11.

142 Shariff A. India: human development report a profile of Indian States in the 1990s. New Delhi: Oxford University Press, 1999.

143 Durbar Mahila Samanwaya Committee. The fallen learn to rise: the social impact of STD/HIV intervention programme, Calcutta, 1998.

144 National AIDS Control Organisation. Combating HIV/AIDS in India 1999-2000. New Delhi: NACO, Government of India, 2000.

145 National AIDS Control Organization. Policy on HIV Testing. URL, 2000: http://www.naco.nic.in/vsnaco/aboutnaco/policies.htm

146 Maniar JK. Health care systems in transition III. India, part II. The current status of HIV/AIDS in India. J Public Health Med 2000;22:33-7.

147 Indian Institute for Health Management. Financing reproductive and child health care in Rajasthan. New Delhi: USAID, 2000.

148 United Nations Development Programme. Human development report 2000 - human rights and human development. New Delhi: UNDP, 2000.

149 Aral SO, Mann JM. Commercial sex work and STD: the need for policy interventions to change societal patterns. Sex Transm Dis 1998:25:455-6. 


\section{FILM REVIEW}

\section{"Kinsey" the film}

Nowadays there are a number of sources that give us relatively unbiased information on what people do at sexual intercourse. One frequently quoted example is the "Sex in America" data-more popularly known as "The Laumann study." We in the United Kingdom of course have a bigger and better one authored by Catherine Mercer and her colleagues. These papers are easily accessible on medical and general computer search engines. But I am pretty sure the average man (or woman) on the Clapham omnibus has neither seen them nor heard of them. In spite of mass sex education in many European countries (this starts at the tender age of 7 in the United Kingdom), I think that what Hollywood portrays is more likely to be accepted as normative behaviour than the findings of population studies. A good example of sexual inaccuracy is in the film "Titanic," where it is implicitly understood that the heroine (Kate Winslet) has an orgasm at her first act of intercourse. We know from scientific data that this is unlikely to happen. What about other older sources? Well, there's the Karma Sutra and the Bible. Sorry, the former only tells us what can be done and the latter tells us what shouldn't be done.

If things are that bad now, at least we, as the supposed literati, can say that normative data are now available. But in the 1930s in Europe and North America (or anywhere else for that matter) neither the general public nor indeed anyone else knew what people did at sex. Then along came Alfred Kinsey in the United States. But who was Alfred Kinsey? I asked a number of my medical and nursing colleagues, and most of them didn't know. If you want to find out and be entertained, go and see the film "Kinsey." I went to see the press showing of this film with a nonmedical journalist friend who is something of a literary sex goddess. She enjoyed the film but felt the content was "shocking." She continued "Can you imagine how much more shocking Kinsey's findings were when they were first published in the early 1950s?"

Kinsey was born in 1894 in Hoboken, New Jersey, and became a biologist with a special interest in gall wasps. This film will tell you how his life changed and he became the first person to study human sexual behaviour systematically as a biologist rather than as a novelist, moralist, or social reformer. Unfortunately while he was highly successful in developing unbiased, valid, reliable interviewing techniques (up to 510 questions at a sitting), his population samples were by no means chosen randomly. Kinsey knew that if he tried for such an unbiased sample he would have high non-response rates (remember this was the 1940s). So his samples came from, for example, sororities, fraternities, and college groups. This film tells us both about Kinsey's work and much about Kinsey the man. He was all at once a happily married man, bisexual, strong minded to the point of arrogance, driven by compulsive data gathering, and finally hounded by Senator MacCarthy and alleged antiAmerican activity to a premature death.

For the general public this film's selling points are likely to be the subject matter (sex), Kinsey's struggle and posthumous victory against the American establishment, and, lastly, the portrayal of his love for his wife. This love, the film asserts, transcended the statistics of his work and sexual matters in general. Rather, love is an ethereal, otherworldly, and spiritual concept. The romantic in me concurs with this notion. The iconoclast/spoiler in me wants to tell you that MRI scans can now isolate the parts of the brain associated with being in love, and that Donatella Marraziti from Italy can convince you that love is merely an obsessional illness.

All that apart, this is an exceptional film. The acting, artistic production, music, and factual accuracy of this film are of a high standard. It is written and directed by Bill Condon (who also wrote the screenplay for Chicago) and stars Liam Neeson as Alfred Kinsey and Laura Linney (Life of David Gale, Lorenzo's Oil) as his wife.

Go and see this 118 minute film. It is educational and entertaining.

You will not be disappointed.

D Goldmeier

Jane Wadsworth Clinic, St Mary's Hospital London W2 INY, UK david.goldmeier@st-marys.nhs.uk

\section{LETTERS}

\section{Uncertainty on the number of HIV/AIDS patients: our experience in Iran}

The article by Grassly et al shows the impact of errors in the national data on HIV/AIDS estimates. ${ }^{1}$ We would like to present our experience with the errors in the official records in Iran that may confound the estimation and expert judgment.

The results of our of HIV/AIDS preventive education in the schools in Iran were released in December $2003 .{ }^{2}$ To do the study, we had to review the only reliable official report in the country-namely, the registry of the Centre for Disease Control (CDC), Ministry of Health and Medical Education (MOHME) of Iran. ${ }^{3}$ Figure 1 depicts the trend of the new cases of HIV/AIDS found in Iran in recent years according to the CDC registry. While reviewing the report with our colleagues in the UNESCO HIV/AIDS Coordination Unit, we noticed fluctuations in the data for the years 1996 and 2001; there are peaks in 1996 and 2001. We checked the data obtained from the CDC and found the data to be in accordance with their records. We then asked about the setting of data collection and found the reason for the peaks. In 1996 and 2001, the prisons throughout the country were tested for HIV by the MOHME and the data were included in the annual reports of the CDC.

Both trafficking and using of drugs are crimes in Iran, and every year large numbers of this high risk population are imprisoned on drug related charges. Records from the CDC show that injecting drug use is the main source of transmission of HIV in Iran $(62.78 \%)$, and sexual contact is said to be the second most important route of transmission, $7.27 \%{ }^{3} ; 26.12 \%$ of the cases, however, are grouped as "unspecified route of transmission." ${ }^{\prime 3}$ This is as long as there is no official record on prevalence of prostitution in Iran. ${ }^{4}$ The MOHME has recently announced an estimated figure of 137000 injecting drug users in Iran. ${ }^{5}$ We should be careful as the statistics from places of concentrated epidemics (for example, prisons) can bias the results and more data are needed to process an accurate estimation of the real number of infected people.

The growing number of new cases can also be because of both the advance in diagnostic methods and the increasing number of the infected people. New cases reported by the Blood Transfusion Organisation of Iran for example make a considerable number of new cases reported by CDC, most of whom are grouped as "unspecified route of transmission."

Accurate data are a must in decision making while expert judgment is needed to interpret the results of the formal statistical inference. ${ }^{1}$ The data presented by the Iranian CDC does not seem to represent the whole population and so cannot be used for

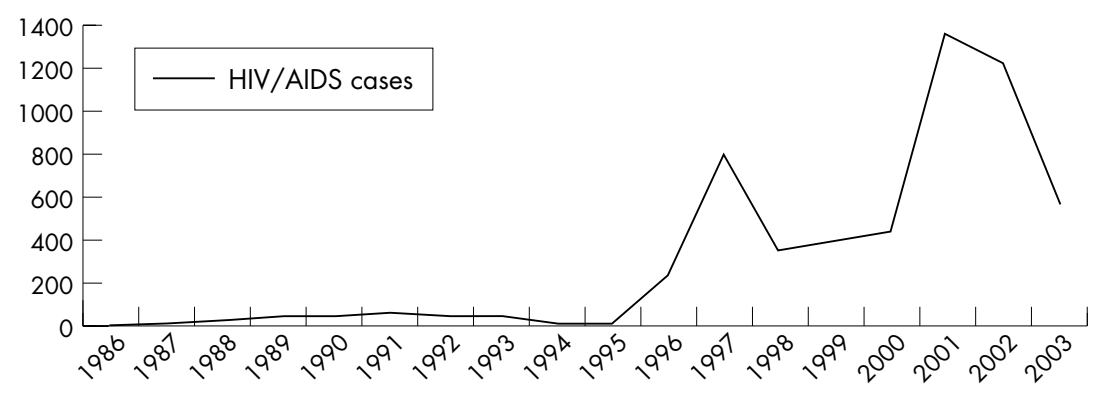

Figure 1 Trend of the new cases of HIV and AIDS patients according to the registry of the CDC, MOHME of Iran (1986-2003). (The data for the year 2003 covers the number of reported cases of HIV/AIDS until September). 
estimation of the real number of patients. Therefore, it is recommended that the CDC explain in detail the setting of the data collection in its periodic reports to safeguard against possible overestimation or underestimation of HIV/AIDS. This can help experts, and especially international agencies such as UNAIDS, to make more accurate estimates of HIV/AIDS. Expert judgment is needed in policy making for such important health issues and official statistics cannot always be trusted.

R Gheiratmand

Bureau of Nutrition and School Health, Deputy of Physical Education and Health, Ministry of Education of the IR Iran, Tehran, Iran

R Navipour

Centre for Research Development, Imam Hospital, Tehran University of Medical Sciences, Tehran, Iran

M R Mohebbi

Faculty of Medicine, Tehran University of Medical Sciences, Tehran, Iran

A K Mallik

HIV/AIDS Coordination and School Health Unit, Asia and Pacific Regional Bureau of Education, UNESCO

Bankok, Thailand

Correspondence to: Dr Mohammed Reza Mohebbi, Faculty of Medicine, Tehran University of Medical Sciences, Tehran, Iran mrmohebbi@yahoo.com

doi: $10.1136 /$ sti.2004.012880

Accepted for publication 6 August 2004

\section{References}

1 Grassly NC, Morgan M, Walker N, et al. Uncertainty in estimates of HIV/AIDS: the estimation and application of plausibility bounds. Sex Transm Infect 2004;80(Suppl 1):131-8.

2 Gheiratmand R, Navipour R, Mohebbi MR, et al. A country study to review existing capacity building and management of the training of teachers on preventive education against HIV/ AIDS in the schools in IR Iran, December 2003. Available from the official website of the Deputy of Physical Education and Health, Ministry of Education of the IR Iran, www.neshat.org/ papers/files/paper_1251.mht (accessed 5 August 2004)

3 Centre for Disease Control, Office of the Undersecretary for Public Health, Ministry of Health and Medical Education of the IR Iran. HIV/ AIDS in Iran (Cumulative Statistics). Tehran, Iran: 2003 (in Persian).

4 Mohebbi MR. Female sex workers and fear of stigmatisation. Sex Transm Infect 2005;81:180-1.

5 The State Prisons and Security and Corrective Measures Organisation, Judiciary of the IR Iran. 137000 injecting drug users in Iran: the population prone to HIV/AIDS. April 2004. (in Persian). Available from the official website of "The State Prisons and Security and Corrective Measures Organisation" www.prisons.ir/farsi/ news.php?news_id = 3980 (accessed 5 August 2004).

\section{Sexual behaviour and high risk human papillomavirus infections in Japanese women}

The increasing incidence of sexually transmitted infection (STI) in young people is one of the most important social and health problems in Japan, ${ }^{1}$ and recent changes in the sexual behaviour may be an important factor. $^{2}$ Cervical human papillomavirus (HPV) infection is one STI and is the major cause of cervical cancer, which is the cancer with the second highest incidence rate and fifth highest cause of cancer death in women worldwide. Japan is an area with the second lowest incidence of cervical cancer worldwide. $^{3}$

To investigate the prevalence of STIs, we performed a cross sectional study of women attending gynaecology departments in the Hokuriku area of Japan from July 2000 to July 2003. In all, 797 women between 15 and 62 years old were selected from about 15000 women who had visited and had a cervical cytology test in one of five clinics during this period. After obtaining written informed consent, all the subjects were given to pelvic examinations, a cervical cytology test, and an STI test using the cervical scraped cell samples. DNA for high risk HPV (HPV types 16, 18, 31, $33,35,39,45,51,52,56,58,59$, and 68), Chlamydia trachomatis, and Neisseria gonorrhoeae was detected using hybrid capture assays (Digene, USA) performed at the Mitsubishi Kagaku Clinical Laboratory in Tokyo (Japan). To document each subject's occupation and sexual behaviour, they were given a questionnaire that they completed independently and returned in a sealed envelope. The questionnaires and clinical data were sent directly to the research centre at Kanazawa University. All of the subjects had the right to refuse to answer any question. Out of 797 subjects, 16 were not eligible owing to lack of information or refusal to complete the questionnaire, and finally 781 women were evaluated in this study.

The age of the eligible subjects was 1559 years: mean age (SD) 29.0 (8.1). The proportion of women who had had sex before the age of 16 years was $21 \%$ ( 160 ), while $23 \%$ of the women had had more than one sexual partner in the previous year (180). Seventy five women $(9.6 \%)$ were currently pregnant and 130 women $(17 \%)$ had undergone an abortion in the past. Of the subjects, 344 women had some symptoms (44\%) suggestive of genital infections, such as vulvovaginal itching or soreness, increased or abnormally coloured vaginal discharge, and lower abdominal pain, and the remaining 437 women had no such symptoms (56\%). Overall, the prevalence of high risk HPV, $C$ trachomatis, and $N$ gonorrhoeae was $24 \%, 5.9 \%$, and $2.2 \%$, respectively. The prevalence of high risk HPV was $50 \%$ in women aged 1519 years, and $37 \%$ in women aged 2024 years (fig 1). The prevalence decreased with age (Kruskal-Wallis test: $\mathrm{p}<0.05$ ). The prevalence of high risk HPV infection was $17 \%(107 / 637)$ in women with normal cytology, 38\% (27/72) in those with atypical squamous cells of undetermined significance (ASCUS), $72 \%(42 / 58)$ in those with low grade squamous intraepithelial lesion (LSIL), and $86 \%(12 / 14)$ in those with high grade squamous intraepithelial lesion (HSIL).

A univariate analysis showed that the risk factors for high risk HPV infection were younger age (15-24 years), unmarried, current smoker, alcohol intake, histories of STD, younger age (12-19 years old) at first sexual intercourse, more than six lifetime sexual partners, frequent sexual intercourse (more than twice/week), current STD in partner, and worried that she might have an STD, while the factors decreasing the risk were history of pregnancy and condom use on all occasions (table 1). By contrast, present clinical symptoms, history of abortion, and current pregnancy were not associated with high risk HPV infections (data not shown). A multivariate analysis using an unconditional logistic

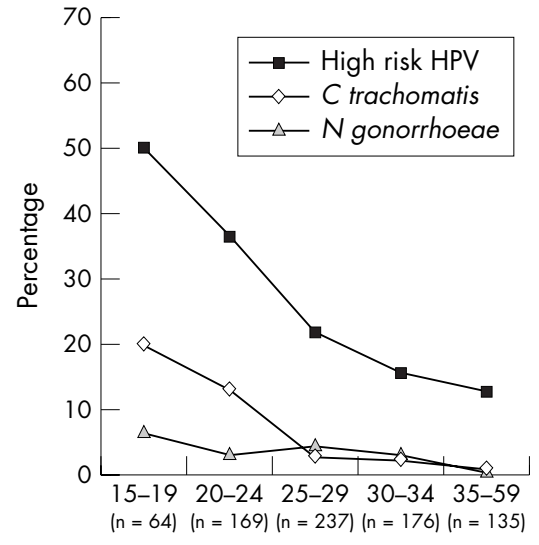

Figure 1 The prevalence of cervical infections according to ages of Japanese women.

regression model revealed that, after controlling for all other variables, being single, a history of STD, thinking she might have an STD, and increased numbers of sexual partners were associated with high risk HPV infection. Evidence for association with younger age at first intercourse, more frequent intercourse and frequent condom use were attenuated. There was no evidence of an association with age, smoking, alcohol intake, history of pregnancy and STD in the partner.

The prevalence of cervical high risk HPV infection in 15-19 year old women in this study was similar to that in Japanese commercial sex workers (CSWs) $(48.4 \%$, mean age 29 years). ${ }^{4}$ Although we have also no way of knowing whether part-time CSWs were included among these subjects, self reporting indicated that there were no professional sex workers. In a previous study of women participating in a cancer screening programme, we found that the prevalence of high risk HPV in women with normal smears (age 16-72 years, mean age 37.0 (SD 13.5) years) was $9.7 \%$, compared with $19 \%$ in this study. ${ }^{5}$ Women selected to be in this study were, however, younger and probably at higher risk of HPV infection, since $44 \%$ had symptoms suggestive of genital infection. The findings suggest that many young Japanese women who are not professional CSW are infected with high risk HPV.

Many studies in other countries have shown that the risk factors for HPV infection are younger age at first sexual intercourse, ${ }^{6}$ a high number of lifetime sexual partners, ${ }^{6-8}$ a high frequency of vaginal $\operatorname{sex}^{7}$ unmarried women, ${ }^{8}$ having anal sex, ${ }^{7}$ having a highly sexually active main partner, ${ }^{79}$ and alcohol

Key message

- This is a first epidemiological study demonstrating high prevalence of cervical high risk HPV infection in Japanese women who are not commercial sex workers

- This clarifies independent risk factors associated with high risk HPV infection in Japan using a multivariate analysis

- A nationwide STD education and prevention programme should be implemented in Japan 
Table 1 Clinical and demographic factors associated with cervical high risk HPV infections in Japan

\begin{tabular}{|c|c|c|c|c|c|c|c|c|}
\hline \multirow[b]{2}{*}{ Variables } & \multicolumn{3}{|c|}{ Prevalence } & \multicolumn{2}{|c|}{ Univariate analysis } & \multicolumn{2}{|c|}{ Multivariate analysis } & \multirow{2}{*}{$\frac{\text { Wald test }}{p \text { Value }}$} \\
\hline & $\begin{array}{l}\text { Total } \\
\text { No }\end{array}$ & $\begin{array}{l}\text { Positive } \\
\text { No }\end{array}$ & $\%$ & $\begin{array}{l}\text { Crude } \\
\text { OR }\end{array}$ & $95 \% \mathrm{Cl}$ & $\begin{array}{l}\text { Adjusted } \\
\text { OR* }^{*}\end{array}$ & $95 \% \mathrm{Cl}$ & \\
\hline \multicolumn{9}{|l|}{ Age (years) } \\
\hline $45-59$ & 50 & 8 & $16 \%$ & 1 & Reference & 1 & Reference & \\
\hline $15-24$ & 233 & 94 & $40 \%$ & 2.5 & $(1.3$ to 4.8$)$ & 1.1 & $(0.43$ to 3.0$)$ & \\
\hline $25-34$ & 413 & 78 & $19 \%$ & 1.2 & $(0.61$ to 2.3$)$ & 0.85 & $(0.35$ to 2.1$)$ & \\
\hline $35-44$ & 85 & 9 & $11 \%$ & 0.66 & $(0.27$ to 1.6$)$ & 0.60 & $(0.20$ to 1.8$)$ & 0.42 \\
\hline \multicolumn{9}{|l|}{ Marriage status } \\
\hline Married & 440 & 66 & $15 \%$ & 1 & Reference & 1 & Reference & \\
\hline Unmarried & 341 & 123 & $36 \%$ & 2.4 & (1.8 to 3.1$)$ & 1.7 & (1.1 to 2.6$)$ & 0.023 \\
\hline \multicolumn{9}{|l|}{ Current smoking } \\
\hline no & 562 & 112 & $20 \%$ & 1 & Reference & 1 & Reference & \\
\hline yes & 219 & 77 & $35 \%$ & 1.8 & (1.4 to 2.3 ) & 1.2 & (0.77 to 1.8$)$ & 0.45 \\
\hline \multicolumn{9}{|l|}{ Alcohol intake } \\
\hline no & 631 & 144 & $23 \%$ & 1 & Reference & 1 & Reference & \\
\hline 1-4 days/week & 119 & 37 & $31 \%$ & 1.4 & (1.01 to 1.8 ) & 1.3 & $(0.78$ to 2.0$)$ & \\
\hline$>4$ days/week & 31 & 8 & $26 \%$ & 1.1 & $(0.61$ to 2.1$)$ & 0.85 & $(0.31$ to 2.3$)$ & 0.58 \\
\hline \multicolumn{9}{|l|}{ Past history of pregnancy } \\
\hline no & 312 & 97 & $31 \%$ & 1 & Reference & 1 & Reference & \\
\hline yes & 469 & 92 & $20 \%$ & 0.63 & (0.49 to 0.81$)$ & 0.76 & (0.50 to 1.2$)$ & 0.22 \\
\hline \multicolumn{9}{|l|}{ Past history of STD } \\
\hline no & 748 & 170 & $23 \%$ & 1 & Reference & 1 & Reference & \\
\hline yes & 33 & 19 & $58 \%$ & 2.5 & (1.8 to 3.5$)$ & 2.9 & (1.3 to 6.4 ) & 0.0083 \\
\hline \multicolumn{9}{|l|}{ Current STD in her partner } \\
\hline no & 731 & 167 & $23 \%$ & 1 & Reference & 1 & Reference & \\
\hline yes & 50 & 22 & $44 \%$ & 1.9 & (1.4 to 2.7$)$ & 0.88 & $(0.41$ to 1.9$)$ & 0.75 \\
\hline \multicolumn{9}{|c|}{ Worried that she might have STD } \\
\hline no & 681 & 144 & $21 \%$ & 1 & Reference & 1 & Reference & \\
\hline yes & 100 & 45 & $45 \%$ & 2.1 & (1.6 to 2.8$)$ & 2.0 & (1.1 to 3.7$)$ & 0.017 \\
\hline \multicolumn{9}{|c|}{ Age at first sexual intercourse (years) } \\
\hline $20-40$ & 259 & 36 & $14 \%$ & 1 & Reference & 1 & Reference & \\
\hline $12-16$ & 160 & 66 & $41 \%$ & 3 & (2.1 to 4.2 ) & 2.0 & $(1.1$ to 3.6$)$ & \\
\hline $17-19$ & 362 & 87 & $24 \%$ & 1.7 & $(1.2$ to 2.5$)$ & 1.2 & (0.77 to 2.0$)$ & 0.069 \\
\hline \multicolumn{9}{|c|}{ Frequency of sexual intercourse in a week } \\
\hline $0-1$ day & 660 & 138 & $21 \%$ & 1 & Reference & 1 & Reference & \\
\hline $2-3$ days & 86 & 34 & $40 \%$ & 1.9 & (1.4 to 2.6$)$ & 1.9 & (1.1 to 3.1$)$ & \\
\hline more than 4 days & 35 & 17 & $49 \%$ & 2.3 & (1.6 to 3.4 ) & 1.4 & $(0.66$ to 3.1$)$ & 0.057 \\
\hline \multicolumn{9}{|c|}{ No of lifetime sexual partners } \\
\hline $0-5$ & 538 & 98 & $18 \%$ & 1 & Reference & 1 & Reference & \\
\hline $6-19$ & 199 & 67 & $34 \%$ & 1.8 & (1.4 to 2.4 ) & 1.3 & (0.84 to 2.0$)$ & \\
\hline more than 20 & 44 & 24 & $55 \%$ & 3.0 & (2.2 to 4.1 ) & 2.8 & (1.4 to 5.8 ) & 0.020 \\
\hline \multicolumn{9}{|l|}{ Frequency of condom use } \\
\hline never or occasionally & 579 & 150 & $26 \%$ & 1 & Reference & 1 & Reference & \\
\hline usually & 81 & 20 & $25 \%$ & 0.95 & (0.64 to 1.4$)$ & 0.77 & (0.42 to 1.4 ) & \\
\hline at all occasions & 121 & 19 & $16 \%$ & 0.61 & (0.39 to 0.94$)$ & 0.58 & (0.33 to 1.0$)$ & 0.145 \\
\hline
\end{tabular}

intake. ${ }^{7}$ In our study, unmarried women, younger age at first sexual intercourse, a high number of lifetime sexual partners, and frequent sex increased the risk of high risk HPV infection. As found in previous studies, Japanese women who practise unsafe sex are at high risk for cervical HPV infection. A unique factor in our study was that a subject who was concerned that she might have an STD was more likely to have an HPV infection. Since current STD in their partner and the presence of clinical symptoms were not associated with HPV infection, unexplained discomfort or recent experience of risky sexual behaviour might be involved. Clinicians should be aware that women who feel that they might have an STD are at high risk for genital HPV infection.

Our study clearly demonstrated that frequent sexual contact with multiple partners at a younger age is likely to be a significant risk factor for high risk HPV infection. A nationwide education and prevention program concerning STD is urgently needed in Japan. Although not all women with high risk HPV develop cervical cancer, ${ }^{10}{ }^{11}$ a percentage of the women with cervical high risk HPV infection do develop cervical cancer decades later. Therefore, the incidence of cervical cancer in younger women might increase with the increase in cervical HPV infection in Japan, as reported in many developed countries. ${ }^{3}$ Regular participation in a cervical cancer screening program starting at 20-25 years of age or from 3 years after the onset of vaginal intercourse is recommended.

\section{Contributors}

TS planned this study, collected clinical samples and information, performed statistical analyses, and wrote this paper; MT, HY, and KAK recorded all data, summarised results, and performed statistical analyses; TF, TTU, TN, SS, and HY collected clinical samples and provided information about clinical data and sexual behaviour of subjects; AS and MI organised the study project and collected some samples.

\section{T Sasagawa, M Tani, H Yasuda, K A Khadijeh,}

A Sakai

School of Health Science, Faculty of Medicine, Kanazawa University, Japan

T Fukae

Fukae Ladies Clinics, Japan

T Ukita

Ukita Hospital, Japan
H Yamazaki

Tsuruga Municipal Hospital, Japan

S Satake, T Nakano

Toyama Prefectural Central Hospital, Japan

$M$ Inoue

Department of Obstetrics/Gynecology, Kanazawa University, Japan

Correspondence to: Toshiyuki Sasagawa, MD, PhD, School of Health Science, Faculty of Medicine, Kanazawa University, 5-11-80 Kodatsuno, Kanazawa, Ishikawa, 920-0942, Japan; tsasa@med. kanazawa-u.ac.jp

doi: $10.1136 /$ sti.2004.011411

Accepted for publication 6 August 2004

Grant: This work is supported by Mitsubishi Kagaku, BCL and Daiichi Seiyaku Co, Japan.

\section{References}

1 Kumamoto $Y$, Tsukamoto T, Kagabe T, et al. STD surveillance 2001 in Japan. Jpn J Sex Transm Dis 2002; 13:147-67.

2 Kihara M, Ono-Kihara M, Feldman MD, et al. HIV/AIDS surveillance in Japan, 1984-2000. $J$ Acquir Immune Defic Syndr 2003;32(Suppl 1): 55-623. 
3 Parkin DM, Bray Fl, Devesa SS. Cancer burden in the year 2000. The global picture. Eur J Cancer 2001;37:S4-S66.

4 Ishi K, Suzuki F, Saito A, et al. Prevalence of human papillomavirus, Chlamydia trachomatis, and Neisseria gonorrhoeae in commercial sex workers in Japan. Infect Dis Obstet Gynecol 2000:8:235-9.

5 Sasagawa T, Walid B, Yamazaki H, et al. High-risk and multiple papillomavirus infections associated with cervical abnormalities in Japanese women. Cancer Epidemiol Biomark Prev 2001 ; 10:45-52.

6 Ley C, Baver HM, Reingold A, et al. Determinants of genital human papillomavirus infection in young women. J Natl Cancer Inst 1991:83:997-1003.

7 Ho GYF, Bierman R, Beardsley L, et al. Natural history of cervicovaginal papillomavirus infection in young women. $N$ Engl J Med 1998;338:423-8.

8 Giuliano AR, Papenfuss M, Schneider, et al. Risk factor for high-risk type human papillomavirus Infection among Mexican-American women. Cancer Epidemiol Biomark Prev 1999;8:615-20

9 Winer RL, Lee SK, Hughes JP, et al. Genital human papillomavirus infection: incidence and risk factors in a cohort of female university students. Am J Epidemiol 2003; 157:218-26.

10 Moscicki AB, Hills N, Shiboski S, et al. Risks for incident human papillomavirus infection and lowgrade squamous intraepithelial lesion development in young females. JAMA 2001;285:2995-3002

11 Molano M, Van den Brule A, Plummer M, et al. Determinants of clearance of human papillomavirus infections in Colombian women with normal cytology: a population-based, 5-year follow-up study. Am J Epidemiol

2003; 158:486-94.

\section{CORRECTION}

The paper by S Hawkes and K G Santhya in the April 2002 issue (Diverse realities: sexually transmitted infections and HIV in India. Sex Transm Inf 2002;78:i31-i39) cited the first author of reference 71 to be Mali JJ-B. That is incorrect, the first author is JV Joshi JV.

If you have a burning desire to respond to a paper published in Sexually Transmitted Infections, why not make use of our eletters" option?

Log onto the STI webste (www.stijournal.com), find the paper that interests you, click on [Abstract] or [Full text] and send your electronic response by clicking on "submit a response". Providing your letter isn't libellous or obscene, it will be posted within seven days. You can view recent eletters by clicking on "Read eletters" on our homepage.

As before, the editors will decide whether to publish the eletter in a further print issue. 